\title{
A Professional Handicraft Teacher in the Eyes of the Student
}

\author{
Ene Lind $^{1} \mathrm{PhD}$; Anne Vahter ${ }^{2}$ \\ Tallinn University, Estonia \\ ene.lind@tlu.ee'; anne.vahter@hotmail.com²
}

\begin{abstract}
The concept of the qualities of a professional teacher has changed over time: today, as a result of social and economic development, there are more and more features, skills, and knowledge that a good teacher needs in order to do their job and interact with the student. However, these qualities may vary depending on the age group the teacher is teaching and the subject they are teaching. Cultural differences also play a major role here. Generally speaking, the characteristics of a teacher's professionalism can be divided into three groups: a teacher as a professional in their field is best described through their general pedagogical skills, subject matter knowledge, and personal qualities. The purpose of this study was to describe the students' vision of a good handicraft teacher. A qualitative research strategy was chosen to conduct the study, and phenomenography was chosen from the research methods, because the purpose of this approach is to describe the experiences being studied, to analyse the descriptions, and to interpret them. Essay writing was chosen as the method of data collection. The sample consisted of fifteen-yearold students from three basic schools in one small town in Estonia. This age grade was chosen because they have had handicraft lessons for five years and are believed to have developed an understanding of the subject and what the teacher should be like. Eighty responses were received. When analysing the works, it was found that the students' opinions regarding general pedagogical skills are the same as those of the previous surveys. However, the expectations of the handicraft teacher differ to some extent. According to the students, the task of the handicraft teacher is to create a free and reliable working environment that requires calmness, empathy, and instructional skills. A handicraft teacher should be a friend and an equal partner who can be trusted to seek advice and discuss life problems.
\end{abstract}

Keywords: handicraft teacher, professionality, students' opinion, school education.

\section{Introduction}

The professionalism of teachers has been the subject of much research, based on different aims and aspects. The views of the first stage of study students have been mapped by K.P. Murphy, L.A.M. Delli, M.N. Edwards (2004) and A. Bakx, M. Koopman, J. de Kruijf, P. den Brok (2014). J.J. Beishuizen, E. van Hof, C.M. Putten, S. Bouwmeester, J.J. Asscher (2001) compared the perception of a good teacher among primary and basic school students and teachers. A similar study comparing the views of a good teacher among students of different age groups has also been conducted in Estonia (Läänemets, Kalamees-Ruubel, Sepp, 2012). The views of teacher education students have been studied by P. Phelan, A.L. Davidson, H.T. Cao (1992), L.B. Chonko, J.F. Tanner, R. Davis (2002) and J. Wilkins (2014).

Based on the number of researches, it can be argued that the teacher's professionalism has been evaluated by different authors on different criteria. According to a survey among teacher education students, the characteristics of professionalism are as follows: the following qualities describe a teacher as a professional in their field (Arnon, Reichel, 2007, 451):

- their subject knowledge because he has a wealth of knowledge and knows what and how to teach;

- their general pedagogical knowledge and skills (including proficiency in methodology, classroom management);

- their personal qualities, that is, they see the students as individuals and associate with each student.

Students and pupils mentioned the following aspects as the most important general pedagogical skills: a professional teacher uses a wide variety of learning methods and learning styles (Mullock, 2003), is able to establish themselves in the classroom (Beishuizen et al., 2001), teaches creatively, they can be counted on, they are able to solve unexpected problems, they can teach students by accepting the differences between them, and they try to encourage the students (Arnon, Reichel, 2007). Such teachers are constantly learning new things and doing research, and they learn from each other and from students (Brownell et al., 2006; Arnon, Reichel, 2007). Students will learn things when they are presented in an 
interesting and age-appropriate manner. The teacher should structure the learning process in such a way that the students are busy learning during the lesson (Brownell et al., 2006; Dislere, 2012) and that it presents students with an intellectual challenge (Mullock, 2003). If the students are busy learning during the lesson, they are less likely to behave badly. Additionally, school stress can be prevented by offering varied and interesting lessons.

Students consider a person who is intelligent and has a thorough knowledge of their subject to be a good teacher. P. Phelan, A.L. Davidson and H.T. Cao (1992) have even noted that it is difficult for students to take seriously teachers who do not have a thorough knowledge of what they are teaching. Students do not want a teacher who gets all their information from a textbook. Instead, they want them to have different perspectives on the topic and to talk to them about various subjects (Läänemets, KalameesRuubel, Sepp, 2012). Students prefer a teacher who is ready and able to help them understand the material they are learning, who takes the time to thoroughly explain the content and ideas, can make the subject understandable, and demonstrates their commitment to their teaching (Phelan, Davidson, Cao, 1992). In addition, students like teachers in whose lessons they understand the material and complex ideas, who teach interesting topics, and enable the students to solve complex problems (Montalvo, Mansfield, Miller, 2007; Mečnnika et al., 2014). It is good to involve more students in lesson planning (Mullock, 2003; Läänemets, Kalamees-Ruubel, Sepp, 2012). This experience develops during teaching and teachers who have just graduated from university may not have it. Therefore, a professional teacher has some experience working with students.

According to research, a good teacher has a wide range of personal qualities: they are caring, patient, interesting, polite, and organised (Murphy, Delli, Edwards, 2004; Loogma, Kesküla, Roosipõld, 2010). S. Arnon and N. Reichel (2007) note that a good teacher is a personal role model for students. Not all of the teacher's personal characteristics mentioned in the research are related to their teaching work, such as having a sense of humour, kindness, fairness, optimism, humanity, determination, and mettle. However, some of them are certainly part of the teaching profession, such as empathy and attentiveness towards students, and their acceptance (Lehtsaar, Krips, Pulver, 2010). It is considered important that the teacher loves and listens to children, engages parents, is flexible, sensitive, forgiving and open, but sets fair boundaries. They are the leader of their class, a person of authority, self-confident and self-disciplined, and able to adapt to different situations. Good communication skills of the teacher come into play when solving behaviour problems. They should have a communication plan for various difficult situations, which requires knowledge of interpersonal communication and behavioural patterns (Lehtsaar, Krips, Pulver, 2010). M.T. Brownell, A. Adams, P. Sindelar, N. Waldron, S. Vanhover (2006) note that a good teacher notices the class as a whole and at the same time, every single student, and knows their needs. Good relationships between teachers and students have been associated with increased student motivation, improved academic performance and student participation, and a general attitude to school (Wilkins, 2014). The work of A. Bakx, M. Koopman, J. de Kruijf, P. den Brok (2014) mentions that a teacher must look appropriate, be exemplary, honest, have the ability to listen to students, and trust them.

The results of the surveys vary slightly depending on the country or stage of study in which the students were interviewed. The differences arise in exactly what one or another age group thinks is important or what are the cultural differences in the requirements of a good teacher. For example, J.J. Beishuizen, E. van Hof, C.M. Putten, S. Bouwmeester, J.J. Asscher (2001) note that basic school students considered good relationships with the teacher important and emphasized the teacher's character traits, while the younger ones focused more on teaching skills.

The aim of this study was to describe the students' vision of a good handicraft teacher, and the following research questions were posed:

- what the students think are the qualities of a good teacher;

- what are the characteristics of a handicraft teacher compared to other teachers?

\section{Methodology}

A qualitative research strategy was chosen to conduct the study, and phenomenography was chosen from the research methods, because the purpose of this approach is to describe the experiences being studied, to analyse the descriptions, and to interpret them. Phenomenography seeks to identify and 
systematise the ways in which people interpret various aspects of reality (Richardson, 1999). As in phenomenography, written works can be used in addition to interviews, drawings, and activity surveys to study people's opinions (Laherand, 2008), an essay was chosen as the method of data collection.

In order to write the short essay, students were asked guiding questions which were formulated based on the categories of teacher professionalism.

- What character traits do you value in a teacher?

- Describe what qualities a handicraft teacher might have that differ from other teachers.

- Should a handicraft teacher set an example in some way?

- Describe how you think the teacher could best make the subject easier for students to understand.

- How can a handicraft teacher make their subject and lessons interesting to students?

The last question was added to enable teachers and students to make suggestions for future work based on the opinions received, as interesting lessons also increase the motivation to learn.

Sampling followed the principle of purposeful sampling (Bogdan, Biklen, 1998). The initial sample consisted of 15-year-old girls of three basic schools in one of Estonia's small towns, who had chosen the field of textile work in their subject area. This age grade was chosen because they have had handicraft lessons for five years and are believed to have developed an understanding of the subject and what the teacher should be like.

Two schools were contacted immediately, and a time was agreed for the study. The teacher from the third school, however, refused to conduct an essay-based study in their classrooms because they felt the spring students had nothing good to say about the teacher. As a result, the plan was changed to include two classes in one school and three in the other.

Prior to starting the essay writing at the school, students were informed about the purpose of the study and that the essays were anonymous. It was also mentioned that the teachers at the same school do not read these works because this way, the students dare to be more honest in expressing their thoughts. In order to ensure the validity of the study, a sample essay was initially conducted in one class, which revealed that the students had a lot of questions about one of the guiding points that was changed as a result.

Eighty essays were written. Three blank papers were also returned from students that did not have any ideas idea about the topic. The data was collected on the basis of the concept of abundance. If the data is sufficient, the replies will be repeated. With this number of essays, the students' thoughts started to repeat, so there was no need to expand the research area and ask more students for their opinion.

The essays were read only by the researchers. For a phenomenographic study, the technique of analysis can be selected in accordance with the data obtained in the study. In this study, the analysis of the research findings had to focus on how students describe a good teacher, rather than investigating and focusing on why they think so. When conducting interviews with students to determine the characteristics of a good teacher, one must always make sure whether the students are describing existing good teachers or whether they would like to have such teachers (Bakx et al., 2014). For this study, students were asked their general opinion and not to describe existing teachers. When analysing the works, it was necessary to consider that students may not understand what qualities make a teacher a professional. They may not notice different teaching methods and techniques; instead, they may only think about whether the lesson is interesting or not. For them, an unprofessional teacher may seem just plain evil and boring. Grade 8 students have had sufficient experiences with different teachers and their work, and as a result, they were expected to be able to comment on the professionalism of teachers.

Coding and categorisation of results were used to analyse the essays. It was observed that the main purpose of coding, which is to separate the text into different parts to understand it and to compose different categorisation, would be followed. According to this understanding, coding involves the constant comparison of phenomena, cases, concepts, etc. Documenting data is thus not a technical part of the research process, but also affects the quality of the data used for interpretation (Flick, 2006).

The coding of the essay was done section by section. Characteristics and activities of the teacher were written down: both what the teacher should do and what a teacher should not be like. Then, the similar codes were merged into one category. The categorisation was based on the research questions. Next, the 
features and activities obtained were grouped again according to the question the students had discussed. Essays were analysed several times to compile different categories.

The research results are presented below in the order of the answers to the research questions, giving typical examples of the students' essays.

\section{Results and Discussion}

There is a wide range of answers to the question "What are the qualities of a good teacher?" The students mentioned the following answers as the most important traits of a teacher:

- explains a lot, understandably, and repeats explanations when needed (47 times);

- teaches essentials life skills, prepares specific and necessary learning content, and directs learning (32 times);

- compiles assignments that match the students' abilities (20 times);

- recognises that students are different, does not hurry, gives students autonomy, knows their weaknesses and develops them (29 times).

A professional teacher should be able to teach and use a variety of learning methods that make classes less varied and active (games, group work) so that "we do not just have to sit all the time".

"Good teaching means that the student does not have to learn independently a lot, the teacher prepares concrete notes with the necessary information, and adds fun and play to the lesson."

"A good teacher must definitely take into account the child's interests. They respect the students and the students respect also them. They try to relate different topics and approaches students individually rather than the class as a whole."

"Good teaching is more than just talking."

In the students' opinion, the teacher should teach the students, rather than having the children do independent work all the time. A good teacher is smart, knows their subject matter, gives subject matter advice and answers questions, teaches in an interesting way, is experienced, and has prepared for the lesson. They should be familiar with the subject, not rely solely on the textbook. It is important that the teacher knows more than the students and is ready to answer the questions immediately. A good teacher motivates the students to learn and the students want to work hard to please them. Based on the attitude of the teacher and the feedback given to the students, it can be seen whether the teacher has faith in themselves and their abilities.

When comparing the results with previous studies, the opinion of Estonian students is relatively similar. The choice of the teacher's tasks and work, and the process of referring the student to them, determine the students' attitudes towards work and their abilities (Dweck, 1986). It is important for students that the teacher selects tasks that are of interest to them and explain the work process clearly. When teachers show interest, enthusiasm, and active engagement in teaching, rather than conveying the learning material in a dull way, the students are more likely to associate themselves with learning (Phelan, Davidson, Cao, 1992) and become good students (Malik, Bashir, 2015). Whether or not a student is interested in the subject and schoolwork depends directly on the teaching methods.

In addition, it is important for students to have fair feedback on their work and the teacher to evaluate their contribution. This shows that the teachers' feedback and attitude towards the students' abilities is crucial because it determines how students see themselves. A number of students highlighted the need for the teacher to motivate students and set an example in their work.

The students also considered it important that the teacher consider the students and their wishes, give them choices, and consider the student's effort and their interests in engaging students in the preparation of the lessons. In spite of everything, the teacher should not start doing in the classroom only what the students want and like. They care about what they convey to their students and try to bring about change in their students. In other words, passionate teachers make students work. L.B. Chonko, J.F. Tanner, R. Davis (2002) find that teaching should be based on the needs of students, and those students may not be aware of them. It is important that the teacher asks the students what they like. The teacher should ask for and take into consideration the students' opinion. Taking the students' views into account when planning the lessons, teachers will make the subject more exciting and motivating for them to work. After all, the teacher 
defines the tasks for the students, gives feedback, and influences at least some of the indicators that determine the motivation to complete the tasks (Montalvo, Mansfield, Miller, 2007; Pridane, 2018).

The students found that the teacher should help with practical tasks, be active in the classroom, use different ways of communicating information (oral, written, visual), inspire students (with examples), create a relaxed working environment, and be polite in their communication. It was also highlighted that a good teacher raises their voice at the right time, does not demand perfection, can bring order to the class, is engaging and emotional, experiments with new things, and motivates students.

It is often difficult to recognise the role of a teacher as a mentor, because the mentoring can take place in a hidden way. In their essays, the students pointed out that a good teacher can be consulted and is a good example with their personality and work. It was also mentioned that a good teacher is like a friend and communicates with the student like a friend, so the student dares to ask them for help and complain to them about their concerns. Teacher education students also note that a teacher is a person who respects their students (Löfström et al., 2010). Teachers think that a good teacher notices the class as a whole and at the same time, every single student (Brownell et al., 2006).

\section{"A good teacher is someone who talks to the student as an equal person, not as a person with} a lower education."

The personal qualities received the most attention from the students, indicating that the students could characterise the teacher as a person more than as an ideal subject teacher and mentor. Students think that a good teacher should have a sense of humour, be friendly, understanding, fun, talkative, and tell interesting stories about life and themselves. On the other hand, they should still be strict, able to establish themselves, have a good attitude towards the class and the students, have good listening skills, and be kind, helpful, confident, and sincere. Students value - teachers who love their job, delve into what they do, want to teach their subject, and are free in their teaching.

Students repeatedly mentioned that when a teacher is cheerful, in a good mood, and positive, it is pleasant and easy to interact with them. A good teacher is flexible, calm, patient, and with a calm voice. Many students mentioned peaceful communication, which may mean that teachers often raise their voices for no good reason. At the same time, it may not achieve the desired result in ensuring discipline (Lehtsaar, Krips, Pulver, 2010).

\section{"It is not good to yell at the students, it makes us "hate" the teacher quickly."}

As in previous studies (Bakx et al., 2014), it was mentioned here that the teacher should look appropriate and nice. It is important for the students that the teacher is an interesting person, intelligent, creative, flexible with the students, and kind and caring about the students. P. Phelan, A.L. Davidson, H.T. Cao (1992) noted that successful students often mean that a caring teacher is a teacher who helps them in school matters. This kind of help shows them that the teacher is concerned about their learning and success. For students who are less successful, caring means showing interest and concern that goes deeper than just helping with schoolwork. For them, it is important for the teacher to show that they like the student as a person, among other things. A good teacher must therefore be interested and care not only for the student's academic success and schoolwork, but also for the student as a person who has their own concerns and joys.

Many students could not describe exactly what a good teacher should be like but described what a good teacher should not be like. For example, students pointed out that the teacher should not yell, get irritated quickly, be too easy-going, but too strict either, belittle anyone in front of the class, hurry, or be evil. We hope that their views have not been shaped by everyday experiences in the classroom.

The students' opinions on whether the handicraft teacher should be different from other subject teachers were varied. There were a few students who felt that all subject teachers can be alike, but most of the respondents thought that a handicraft teacher still has to and does differ from other teachers in their personal characteristics.

The distinctive characteristics of a handicraft teacher stemmed primarily from the content of the subject and the nature of the teaching. As the lesson is largely practical and not all students may be as skilled as the teacher would like them to be, the most important distinguishing feature of a handicraft teacher in the students' opinion is that they are calm, their reaction to different situations in the classroom is 
composed, and unexpected moments in the classroom do not irritate them. Instead, they must be able to maintain peace and help the students. In addition, it was pointed out that a handicraft teacher should be patient with the students, as not everyone may succeed in the tasks at first try.

"The handicraft teacher should be twice as patient as other teachers, because handicraft is not easy for everyone and succeeding in it takes time."

The relaxed character of the handicraft teacher was also mentioned in connection with the explanation of new subjects, instructions, and tasks, since it takes some students to understand the texts and drawings. The students noted that if necessary, the new topic should be explained as long as everyone understands it. It is also important that the teacher not only explains the task at the beginning of the lesson, but also during the practical work. A good handicraft teacher helps the students: verbal guidance is not enough for everyone - sometimes, the teacher must show how to do what is needed or even do the most difficult parts for the students. They should evaluate the students equally and individually in accordance with their ability. Students think that handicraft is a creative subject and that teachers should have a more relaxed approach to it.

\section{"The handicraft teacher should be able to take into account the abilities of all children."}

At the same time, in the students" opinion, they cannot be too compromising all the time - "sometimes, they have to be very strict".

A good handicraft teacher does not spend the whole lesson behind their desk. Instead, they pay attention to what the students are doing, keep track of their progress, and tell them right away when they are doing something wrong. M.T. Brownell, A. Adams, P. Sindelar, N. Waldron, S. Vanhover (2006) point out that a good teacher notices those who are struggling and gives them personalised help. Students want the teacher to do educational games in the classroom, carry out some lessons outdoors, and implement different learning styles. In addition, students want more movement during handicraft classes as "it is difficult for some people to stay in one place for a long time".

"The lesson can be made more interesting by doing more practical work and less writing and tests. After all, it is a creative subject."

In the essays, students pointed out that a good handicraft teacher is an example to the students in terms of knowledge, work, and personality. A good handicraft teacher should be fashion-conscious, creative, interested in handicraft, and skilled in what they do. A good role model will help students do a better job, and if the teacher is good role model, it may motivate students to choose their profession.

"I think a handicraft teacher should set a good example, because surely some students will choose the teaching profession because their teacher was or is so nice and friendly."

The handicraft teacher is expected to create a good working environment in the classroom so that "the class will be pleasant and enjoyable". The students mentioned that the handicraft teacher should understand that not everyone is skilled in handicraft and that they are not able to do everything perfectly and, for example, postpone the deadlines in accordance with the student's abilities. It is important for the students that the teacher let them interact with each other during the practical work once the instructions have been given. In addition, the teacher should talk to the students. It was pointed out that the handicraft teacher should tell stories during their lessons and let the students interact with each other. The handicraft teacher should be a friend to the students and be treat them as equals, so the students would trust them to seek advice on things other than handicraft. Students want to be able to turn to the teacher with their concerns so that the teacher could help them.

"Students should be able to trust the handicraft teacher could so much that they could ask them for advice whether it is handicraft-related or not."

They must be able to advise on the subject, teach various life skills, and set a good example because the subject is vital. It is important for students that the teacher is able to explain to them why they are learning the subject and how handicraft will help them in the future. 
In terms of additional questions on making the handicraft lessons more interesting, students suggested the following:

- the teacher introduces new topics to the students in a motivating way;

- the teacher tells the students what they themselves have made in one technique or another;

- the teacher can give interesting subject-specific examples.

The lessons become more interesting as soon as the teacher teaches techniques other than the classic everyday handicraft techniques (knitting, crocheting, embroidery).

"Handicraft lessons can be made more interesting by having the teacher show new and exciting patterns or works."

In addition, it was found that the teacher should give students more autonomy and develop creativity by letting them choose their own task/project and finding interesting work instructions for the lesson. Even if the teacher has prepared everything, they should give the students a choice. The choices give the student the opportunity to decide what they like the most and therefore, they have more motivation to do so. This should be the case for larger and more complex jobs (such as sewing), so that the student can choose the task and technique appropriate to their abilities. The choice of tasks by the teacher and the process of assigning the student to them determine the student's attitude towards their tasks and abilities (Dweck, 1986). Showing beautiful and well-done examples to the students is very helpful as this way, they want to do something similar by themselves as well.

\section{Conclusions}

Comparing the results of this study with previous student surveys to characterise a professional teacher, it can be said that the students' opinions on general pedagogical skills overlap. The teacher is expected to know the subject matter, master different methodologies, be motivated, be able to give fair feedback, and to establish themselves in the classroom. These qualities are important no matter what subject the teacher is teaching.

However, there is a certain difference in the expectations placed on the handicraft teacher, especially in terms of personal qualities. As handicraft lessons mainly develop creativity and manual skills, and help the students acquire the basic skills for everyday life, it is the task of the teacher to create a free and reliable working environment that requires calmness, empathy, and guidance. The students expect the handicraft teacher to be a friend and an equal partner who can be trusted to seek advice and discuss life problems.

The results of the survey cannot be generalised as the results were the opinions of the students of only two schools. At the same time, the students' thoughts started to repeat in the essays, so there was no need to expand the research area and ask more students for their opinions.

\section{Bibliography}

1. Arnon S., Reichel N. (2007). Who is the ideal teacher? Am I? Similarity and difference in perception of students of education regarding the qualities of a good teacher and of their own qualities as teachers. Teachers and Teaching: theory and practice, 13(5), 441-464. doi: 10.1080/13540600701561653

2. Bakx A., Koopman M., de Kruijf J., den Brok P. (2014). Primary school pupils' view of characteristics of good primary school teachers: an exploratory, open approach for investigating pupils' perceptions. Teachers and Teaching: theory and practice, 21(5), 543-564. doi: 10.1080/13540602.2014.995477

3. Beishuizen J.J., van Hof E., Putten V.C.M., Bouwmeester S., Asscher J.J. (2001). Students' and teachers' cognitions about good teachers. British Journal of Educational Psychology, 71(2), 185201. doi: 10.1348/000709901158451

4. Bogdan R.C., Biklen S.K. (1998). Qualitative research for education: An Introduction to theory and methods $\left(3^{\text {rd }}\right.$ ed.). Boston: Allyn \& Bacon. Retrieved from https://eric.ed.gov/?id=ED419813

5. Brownell M.T., Adams A., Sindelar P., Waldron N., Vanhover S. (2006). Learning From Collaboration: The Role of Teacher Qualities. Exceptional Children, 72(2), 169-185. doi: $10.1177 / 001440290607200203$ 
6. Chonko L.B., Tanner J.F., Davis R. (2002). What Are They Thinking? Students' Expectations and Self-Assessments. Journal of Education for Business, 77(5), 271-281. doi: 10.1080/08832320209599676

7. Dislere V. (2012). Methodology Structure for Training Teachers of Home Economics and Technologies. In V. Dislere (Ed.), The Proceedings of the International Scientific Conference Rural Environment. Education. Personality (REEP), 5. Jelgava: LLU, 201-208. Retrieved from https://llufb.llu.lv/conference/REEP/2012/REEP-2012-proceedings-E-ISSN-2255-808X.pdf

8. Dweck C.S. (1986). Motivational Processes Affecting Learning. American Psychologist, 41(10), 1040-1048. doi: 10.1037/0003-066X.41.10.1040

9. Flick U. (2006). An introduction to qualitative research (3 $3^{\text {rd }}$ ed.). London, Thousand Oaks: SAGE Publications Ltd.

10. Laherand M.-L. (2008) Kvalitatiivne uurimisviis [Qualitative research]. Tallinn: Infotrükk. (in Estonian).

11. Lehtsaar T., Krips H., Pulver A. (2010). The Structure of the Social Competence of Estonian School Teachers. In J. Mikk, M. Veisson, P. Luik (Eds.), Teacher's Personality and Professionalism. Frankfurt am Main: Peter Lang, 75-86.

12. Loogma K., Kesküla E., Roosipõld A. (2010). The Transformation of the Teaching Profession in Estonia: Changes in Professionalism. In J. Mikk, M. Veisson, P. Luik (Eds.), Teacher's Personality and Professionalism. Frankfurt am Main: Peter Lang, 11-30.

13. Läänemets U., Kalamees-Ruubel K., Sepp A. (2012). What Makes a Good Teacher? Voices of Estonian Students. Delta Kappa Gamma Bulletin, 79(1), 27-31. Retrieved from https://www.questia.com/library/journal/1P3-2759918441/what-makes-a-good-teacher-voicesof-estonian-students

14. Löfström E., Anspal T., Hannula M.S., Poom-Valickis K. (2010). Metaphors About 'The Teacher': Gendered, Discipline-Specific and Persistent? In J. Mikk, M. Veisson, P. Luik (Eds.), Teacher's Personality and Professionalism. Frankfurt am Main: Peter Lang, 104-121.

15. Malik A.N., Bashir S. (2015). Good teacher; student's perception about top qualities in health sciences. The Professional Medical Journal, 22(5), 670-673. Retrieved from http://theprofesional.com/index.php/tpmj/article/view/1309

16. Mečņika V., Hoerr M., Krieviņš I., Schwarz A. (2014). Smart textiles for healthcare: applications and technologies. In V. Dislere (Ed.), The Proceedings of the International Scientific Conference Rural Environment. Education. Personality (REEP), 7. Jelgava: LLU, 150-161. Retrieved from https://llufb.llu.lv/conference/REEP/2014/Latvia-Univ-Agricult-REEP-2014proceedings-150-161.pdf

17. Montalvo G.P., Mansfield E.A., Miller R.B. (2007). Liking or Disliking the Teacher: Student Motivation, Engagement and Achievement. Evaluation and Research in Education, 20(3), 144-158. doi: $10.2167 /$ eri406.0

18. Mullock B. (2003). What makes a good teacher? The perceptions of postgraduate TESOL students. Prospect, 18(3), 3-24. Retrieved from http://www.ameprc.mq.edu.au/docs/prospect_journal/volume_18_no_3/18_3_1_Mullock.pdf

19. Murphy K.P., Delli L.A.M., Edwards M.N. (2004). The Good Teacher and Good Teaching: Comparing Beliefs of Second-Grade Students, Preservice Teachers, and Inservice Teachers. The Journal of Experimental Education, 72(2), 69-92. doi: 10.3200/JEXE.72.2.69-92

20. Phelan P., Davidson A.L., Cao H.T. (1992). Speaking Up: Students' Perspectives on School. The Phi Delta Kappan 73(9), 695-704.Retrieved from http://www.jstor.org/stable/20404741

21. Pridane A. (2018). Development of Learning and Feedback Giving Skills in Home Economics and Technologies Education. In V. Dislere (Ed.), The Proceedings of the International Scientific Conference Rural Environment. Education. Personality (REEP), 11. Jelgava: Latvia University of Life Sciences and Technologies, 321-327. doi: 10.22616/REEP.2018.039

22. Richardson J.T.E. (1999). The Concepts and Methods of Phenomenographic Research. Review of Educational Research, 69(1), 53-82. Retrieved from https://www.cedu.niu.edu/ walker/research/Phenomenology.pdf

23. Wilkins J. (2014). Good Teacher-Student Relationships: Perspectives of Teachers in Urban High Schools. American Secondary Education, 43(1), 52-68. Retrieved from https://eric.ed.gov/?id=EJ1047050 